\title{
Ekspresi Vascular Endothelial Growth Factor dan Ekspresi Tissue Factor berdasarkan Respons Terapi Kemoradiasi Cisplatin pada Penderita Karsinoma Nasofaring Stadium Lanjut
}

\author{
Een Hendarsih, ${ }^{1}$ Amaylia Oehadian, ${ }^{2}$ Rachmat Sumantri, ${ }^{2}$ Iman Supandiman, ${ }^{2}$ Bethy S. Hernowo ${ }^{3}$ \\ ${ }^{1}$ Staf Medis Fungsional Ilmu Penyakit Dalam Rumah Sakit Haji Surabaya, ${ }^{2}$ Divisi Hematologi Onkologi Medik \\ Departemen Ilmu Penyakit Dalam Rumah Sakit Dr. Hasan Sadikin Bandung, ${ }^{3}$ Departemen Patologi Anatomiumah \\ Rumah Sakit Dr. Hasan Sadikin Bandung
}

\begin{abstract}
Abstrak
Vascular endothelial growth factor (VEGF) merupakan faktor angiogenik yang berperan dalam angiogenesis tumor. Tissue factor (TF) merupakan inisiator utama pembekuan darah dan merangsang protein yang mengatur angiogenesis. Penelitian bertujuan mengetahui perbedaan ekspresi VEGF dengan ekspresi TF pada penderita KNF stadium lanjut berdasarkan respons terapi kemoradiasi. Dilakukan penelitian kohort prospektif pada penderita KNF stadium III, IVa, dan IVb berdasarkan AJCC edisi ke-7 tahun 2010. Ekspresi TF dan VEGF diperiksa dengan imunohistokimia dan respons kemoradioterapi dievaluasi dengan memakai Response Evaluation Criteria in Solid Tumours (RECIST) revisi versi 1.1 tahun 2009. Analisis statistik yang digunakan adalah Uji eksak Fisher. Selama penelitian Oktober 2012-Oktober 2013 didapatkan 35 penderita KNF yang memenuhi kriteria inklusi dan 5 orang dikeluarkan dari penelitian. Pada kelompok respons didapatkan 17 dari 23 penderita ekspresi VEGF $\geq 25 \%$; 6 dari 23 penderita ekspresi VEGF <25\%; 16 dari 23 penderita ekspresi TF $\geq 33 \%$; 7 dari 23 penderita ekspresi TF $<33 \%(\mathrm{p}=1,000)$ serta pada kelompok tidak respons 5 dari 27 penderita ekspresi VEGF $\geq 25 \% ; 2$ dari 7 penderita ekspresi VEGF $<25 \%$; 4 dari 7 penderita ekspresi TF $\geq 33 \%$; 3 dari 7 penderita ekspresi TF $<33 \%$ $(\mathrm{p}=0,657)$. Simpulan, tidak terdapat perbedaan ekspresi VEGF dengan ekspresi TF pada penderita KNF stadium lanjut berdasarkan respons terapi kemoradiasi. [MKB. 2015;47(1):49-54]
\end{abstract}

Kata kunci: Karsinoma nasofaring, respons kemoradiasi, tissue factor, vascular endothelial growth factor

\section{Differences between Vascular Endothelial Growth Factor Expression and Tissue Factor Expression Based on Cisplatin Chemoradiation Therapy Response in Advanced Stage Nasopharyngeal Cancer}

\begin{abstract}
Vascular endothelial growth factor (VEGF) is a proangiogenic factor involved in the angiogenesis of NPC. Tissue factor (TF), the main initiator of blood coagulation, also signals protein that regulates angiogenesis. This study analyzed the differences between VEGF expression and TF expression in tumor tissue based on chemoradiation therapy response. Prospective cohort study was performed in NPC patients stage III, IVa and IVb according to the AJCC VII staging system. TF expression and VEGF expression were measured by immunohistochemistry, and chemoradiotherapy responses was evaluated by RECIST version 1.12009 . Statistical analysis was performed using Fisher Exact test. From October 2012 to October 2013, 35 NPC patients were eligible for this study and 5 patients were excluded. In response group, there were $73.9 \%$ patients with VEGF expression $\geq 25 \%, 26.1 \%$ patients with VEGF expression <25\%; 69.6\% patients with TF expression $\geq 33 \%, 30.4 \%$ patients with TF expression $<33 \%$ $(p=1,000)$ and in no response group, there were $71,4 \%$ patients with VEGF expression $\geq 25 \%$; $28.6 \%$ patients with VEGF expression $<25 \%, 57.1 \%$ patients with $\mathrm{TF}$ expression $\geq 33 \%, 42.9 \%$ patients with $\mathrm{TF}$ expression $<33 \%$ ( $\mathrm{p}=0.657$ ). In conclusion, there are differences between VEGF expression and TF expression based on the chemoradiation therapy response, but they are not significantly different. [MKB. 2015;47(1):49-54]
\end{abstract}

Key words: Nasopharyngeal carcinoma, chemoradiation response, tissue factor, vascular endothelial growth factor

Korespondensi: Een Hendarsih, dr., Sp.PD, RSU Haji Surabaya Jalan Manyar Kertoadi Surabaya 60117, mobile 08131186525, e-mail: hendarsih_een@hotmail.com 


\section{Pendahuluan}

Karsinoma nasofaring atau KNF merupakan keganasan kepala dan leher yang paling sering ditemukan di Cina Selatan dan Asia. ${ }^{1}$ Karsinoma nasofaring di Indonesia terbanyak terjadi pada usia di atas 40 tahun dengan prevalensi sebesar $4,7 / 100.000$ penduduk per tahun. ${ }^{2}$

Penatalaksanaan pasien KNF hingga saat ini masih belum memuaskan. Karsinoma nasofaring bersifat radiosensitif maka radioterapi hingga saat ini masih sebagai modalitas terapi standar. Pada stadium lanjut nonmetastasis, kombinasi dengan kemoterapi merupakan terapi pilihan. ${ }^{3}$ Cisplatin masih merupakan regimen terpilih, baik sebagai kemoterapi yang konkuren ataupun sebagai radiosensitasi pada pasien KNF. Walau memberikan angka kesembuhan yang cukup tinggi, angka kegagalan atau resistensi terhadap terapi kemoradiasi masih sering kali ditemukan. Pada stadium III dan IV, angka kegagalan respons lokal dan metastasis jauh mencapai 50\%. ${ }^{4}$

Seiring berkembangnya pengetahuan tentang biologi molekuler pada kanker, banyak penelitian molekuler yang dilakukan untuk menentukan faktor prediktor penatalaksanaan KNF. Penelitian yang dilakukan fokus pada faktor biologi yang memengaruhi radiosensitivitas tumor adalah indeks proliferasi (Ki-67, EGFR), efek oksigen yang direfleksikan oleh neovaskularisasi (MVD, VEGF), dan apoptosis (p53, Bcl-2). ${ }^{5}$ Penelitianpenelitian tersebut memperlihatkan hasil yang berbeda-beda sehingga makna klinis tiap faktor tersebut sampai waktu ini masih belum dapat dipastikan.

Angiogenesis merupakan proses dasar dalam pertumbuhan tumor dan metastasis. Vascular endothelial growth factor atau VEGF diketahui secara luas sebagai faktor permeabilitas vaskular dan dipergunakan sebagai marka angiogenesis. Data peran VEGF pada kanker kepala dan leher termasuk KNF masih kurang jika dibandingkan dengan peran VEGF pada keganasan lain dan nilai prognostik VEGF juga masih belum jelas. ${ }^{6}$

Berbagai cara mekanisme dapat meregulasi ekspresi VEGF tetapi yang terpenting adalah hipoksia. HIF-1 $\alpha$ merupakan mediator utama terhadap respons hipoksia tersebut. Vascular endothelial growth factor dalam sel-sel tumor selain distimulasi oleh hipoksia juga dinduksi oleh onkogen (ras) dan inaktivasi gen supresor tumor ( $p 53)$ serta berbagai sitokin. ${ }^{7}$

Beberapa penelitian telah menemukan peran tissue factor (TF) terhadap kejadian metastasis, angiogenesis, dan juga pertumbuhan tumor. ${ }^{8}$ Mekanismenya adalah bahwa ikatan faktor VIIa dengan TF mengakibatkan proteolisis PAR-2 dan fosforilasi domain sitoplasma TF sehingga mengaktivasi jalur sinyal sel yang pada akhirnya akan menyebabkan angiogenesis, kelangsungan hidup sel ganas, dan metastasis. ${ }^{8,9}$

Tissue factor (TF) diekspresikan pada semua tipe kanker. Keadaan hipoksia jaringan akan mengekspresikan HIF2 $\alpha$ sehingga menginduksi ekspresi TF pada sel endotel dan monosit. ${ }^{10,11}$ Selain keadaan hipoksia, ekspresi TF pada sel kanker juga disebabkan oleh onkogenik spesifik sebuah tumor. Seperti mutasi ras dan hilangnya fungsi p53 pada kanker kolorektal; mutasi ras pada karsinoma sel skuamosa; mutasi EGFR dan hilangnya fungsi $E$ cadherin pada glioblastoma akan meningkatkan ekspresi TF. $^{10}$

Penelitian ini memiliki tujuan mengetahui perbedaan ekspresi TF dengan ekspresi VEGF berdasarkan respons terapi kemoradiasi pada KNF stadium lanjut.

\section{Metode}

Penelitian ini merupakan suatu penelitian kohort prospektif yang dilakukan dari bulan Oktober 2012 sampai Oktober 2013 pada penderita KNF stadium III, IVa, IVb yang menjalani terapi konkomitan kemoradiasi dengan cisplatin yang pertama kali berobat ke poliklinik HematologiOnkologi Medik, poliklinik THT, atau penderita yang dirawat di ruang Rawat Inap Bagian Ilmu Penyakit Dalam dan THT RSHS Bandung. Kriteria inklusi adalah penderita KNF stadium III, IVa, dan IVb berdasarkan American Joint Committee on Cancer (AJCC) edisi ke-7 2010, histopatologi sesuai kriteria WHO II dan III yang dikonfirmasi dengan dilakukannya pemeriksaan imunohistokimia sitokeratin, usia 18-60 tahun, penderita KNF yang akan mendapatkan terapi kemoradiasi konkuren cisplatin, sediaan biopsi berasal dari biopsi nasofaring, status perfoma WHO $0-2$, dan hemoglobin $\geq 10 \mathrm{~g} / \mathrm{dl}$. Kriteria eksklusi yaitu gangguan fungsi ginjal, diabetes melitus, vaskulitis, dan penyakit kolagen.

Semua subjek penelitian dilakukan staging sebelum terapi kemoradiasi dengan CT-scan nasofaring, foto toraks, ultrasonografi abdomen, hematologi lengkap, dan kimia darah. Subjek penelitian mendapat terapi kemoradiasi dengan cisplatin $100 \mathrm{mg} / \mathrm{m}^{2}$ pada hari ke-1, ke-22, dan ke-43 radioterapi dengan dosis radioterapi 70 Gy. Evaluasi terapi dengan CT-scan dilakukan minimal empat minggu setelah terapi terakhir. Respons terapi dinilai dengan mempergunakan Response Evaluation Criteria in Solid Tumours 
(RECIST) revisi versi 1.1 tahun 2009 tanpa melakukan pemeriksaan sumsum tulang.

Ekspresi VEGF diperiksa dengan memotong blok parafin ketebalan 3-5 $\mu \mathrm{m}$, jika sediaan biopsi mengandung area nekrosis, sediaan tidak digunakan untuk analisis. Aktivitas peroksidase endogen dihambat mempergunakan hidrogen peroksidase 3\% dalam metanol 10 menit dalam suhu ruangan. Potongan ini lalu diinkubasikan dalam plasma domba 10\% dalam phosphatebuffered saline (PBS) selama kurang lebih 30 menit, lalu dilanjutkan inkubasi pada suhu $4^{\circ} \mathrm{C}$ dengan menggunakan monoclonal mouse antihuman VEGF clone VG1 (Dako) selama semalam. Sesudah itu tiap-tiap slide diberi biotinylated antirabbit immunoglobulin selama waktu 10 menit kemudian diinkubasikan dengan streptavidinperoxidase complex selama 45 menit. Aktivitas peroksidase divisualisasikan mempergunakan 3,3'-diaminobenzidine dan juga pewarnaan inti memakai cairan hematoksilin. Ekspresi VEGF dievaluasi dengan menghitung rata-rata jumlah sel yang terwarna tiap 100 sel dalam 5 lapang pandang pada pembesaran 400x. Ekspresi TF diperiksa dengan cara yang sama namun dengan menggunakan antibodi TF (orb100189 Biorbyt, UK).

Nilai positif distribusi sel tumor adalah nilai semikuantitatif dinyatakan dalam persentase distribusi dengan intensitas warna coklat/lapang pandang mikroskop cahaya dengan pembesaran 400 kali. Penelitian ini mempergunakan nilai batas ekspresi VEGF $\geq 25 \%$ sebagai ekspresi VEGF tinggi dan $<25 \%$ sebagai ekspresi VEGF rendah sebagaimana digunakan pada penelitian Kurnianda dkk., ${ }^{6}$ sedangkan ekspresi $\mathrm{TF} \geq 33 \%$ yaitu sebagai ekspresi TF yang tinggi dan $<33 \%$ sebagai ekspresi TF rendah yang juga digunakan dalam penelitian Regina dkk. ${ }^{12}$ pada karsinoma paru.

Analisis statistik yang digunakan deskriptif untuk menghitung distribusi ekspresi VEGF dan ekspresi TF berdasarkan respons terapi serta analisis perbedaan data dipakai chi-kuadrat atau Uji eksak Fisher apabila nilai ekspektasi kurang dari 5. Penelitian ini dilakukan setelah mendapat persetujuan dan juga rekomendasi dari Komite Etik Penelitian Kesehatan Fakultas Kedokteran Universitas Padjadjaran/Rumah Sakit Dr. Hasan Sadikin Bandung.

\section{Hasil}

Subjek penelitian yang dapat dianalisis sebanyak 30 orang berusia antara 19 sampai 60 tahun,
Tabel 1 Karakteristik Subjek Penelitian

\begin{tabular}{|c|c|}
\hline Jenis kelamin & $n=30$ \\
\hline Laki-laki & 19 \\
\hline Perempuan & 11 \\
\hline \multicolumn{2}{|l|}{ Usia } \\
\hline Rerata & $39,97 \pm 11,33$ \\
\hline Median & 38.5 \\
\hline \multicolumn{2}{|l|}{ Stadium } \\
\hline IVa & 13 \\
\hline $\mathrm{IVb}$ & 17 \\
\hline \multicolumn{2}{|l|}{ Tumor } \\
\hline $\mathrm{T} 1$ & 9 \\
\hline $\mathrm{T} 2$ & 6 \\
\hline T3 & 5 \\
\hline $\mathrm{T} 4$ & 10 \\
\hline \multicolumn{2}{|l|}{ Nodul } \\
\hline N0 & 2 \\
\hline N1 & 1 \\
\hline $\mathrm{N} 2$ & 17 \\
\hline N3 & 10 \\
\hline \multicolumn{2}{|l|}{ Respons terapi } \\
\hline Respons & 23 \\
\hline Tidak respons & 7 \\
\hline
\end{tabular}

terdiri atas 19 orang laki-laki dan 11 orang perempuan dengan median usia 38,5 tahun (1960 tahun). Subjek penelitian terdiri atas 13 orang stadium IVa dan 17 orang stadium IVb (Tabel 1).

Respons terapi subjek penelitian terbagi atas 2 kelompok yaitu kelompok respons dan tidak respons. Pada kelompok respons terdapat 23 orang yang terdiri atas 1 orang respons komplet, 21 orang respons parsial, dan 1 orang stable disease dan pada kelompok tidak respons terdapat 7 orang progressive disease.

Tabel 2 Ekspresi VEGF berdasarkan Respons Terapi

\begin{tabular}{|c|c|c|c|}
\hline \multicolumn{3}{|c|}{ Terapi } & \multirow[b]{2}{*}{ Nilai $p$} \\
\hline $\begin{array}{l}\text { Ekspresi } \\
\text { VEGF }\end{array}$ & $\begin{array}{c}\text { Respons } \\
n=23\end{array}$ & $\begin{array}{c}\text { Tidak Respons } \\
\mathbf{n}=7\end{array}$ & \\
\hline$\geq 25 \%$ & 17 & 5 & 1,000 \\
\hline$<25 \%$ & 6 & 2 & \\
\hline
\end{tabular}

Keterangan: Analisis menggunakan Uji eksak Fisher *bermakna jika $\mathrm{p}<0,05$ 
Tabel 3 Ekspresi TF berdasarkan Respons Terapi

\begin{tabular}{|c|c|c|c|}
\hline \multicolumn{3}{|c|}{ Terapi } & \multirow{2}{*}{$\begin{array}{c}\text { Nilai } \\
\mathbf{p}\end{array}$} \\
\hline Ekspresi TF & $\begin{array}{c}\text { Respons } \\
\mathrm{n}=23\end{array}$ & $\begin{array}{c}\underset{\mathbf{T}}{\text { Tidak Respons }} \\
\mathbf{n}=7\end{array}$ & \\
\hline$\geq 33 \%$ & 16 & 4 & 0,657 \\
\hline$<33 \%$ & 7 & 3 & \\
\hline
\end{tabular}

Keterangan: Analisis menggunakan Uji eksak Fisher *bermakna jika $\mathrm{p}<0,05$

Pada kelompok respons didapatkan 17 orang ekspresi VEGF $\geq 25 \%$ dan 6 orang berekspresi VEGF $<25 \%$, sedangkan pada kelompok tidak respons didapatkan sebanyak 5 orang ekspresi VEGF $\geq 25 \%$ dan 2 orang ekspresi VEGF $<25 \%$ (Tabel 2). Untuk melihat perbedaan ekspresi VEGF berdasarkan respons terapi dilakukan Uji eksak Fisher dan didapatkan hasil $p=1,000$ yang artinya tidak terdapat perbedaan ekspresi VEGF baik pada kelompok respons maupun kelompok tidak respons.

Pada kelompok respons didapatkan 16 orang ekspresi TF $\geq 33 \%$ dan 7 orang berekspresi TF $<33 \%$, sedangkan pada kelompok tidak respons didapatkan 4 orang ekspresi $\mathrm{TF} \geq 33 \%$ dan 3 orang ekspresi $\mathrm{TF}<33 \%$ (Tabel 3). Untuk dapat melihat perbedaan ekspresi $\mathrm{TF}$ berdasarkan respons terapi dilakukan Uji eksak Fisher dan didapatkan $\mathrm{p}=0,657$ yang berarti tidak terdapat perbedaan ekspresi TF baik pada kelompok respons maupun kelompok tidak respons.

\section{Pembahasan}

Vascular endothelial growth factor merupakan salah satu parameter faktor biologi yang banyak diteliti sebagai prognosis pada KNF., ${ }^{6,13,14}$ Faktor VEGF tersebut adalah faktor angiogenik yang merupakan kekuatan utama angiogenesis tumor dan pembentukan seluruh pembuluh darah. ${ }^{7}$ Angiogenesis tumor merefleksikan efek oksigen yang sangat berpengaruh pada radiosensitivitas sebuah tumor. ${ }^{9}$ Oksigen terlarut pada jaringan meningkatkan stabilitas dan toksisitas radikal bebas sehingga sel menjadi sensitif terhadap radioterapi..$^{15}$

Pada penelitian didapatkan subjek dengan ekspresi VEGF tinggi ( $\geq 25 \%$ ) pada 22 orang dan ekspresi VEGF rendah $(<25 \%)$ sebanyak 8 orang (Tabel 2). Dari 22 orang dengan ekspresi VEGF tinggi didapatkan 17 orang respons terhadap terapi kemoradiasi dan 5 orang tidak respons. Keadaan ini sesuai dengan hipotesis penelitian ini yang mendukung teori bahwa angiogenesis merefleksikan oksigen pada jaringan tumor sehingga sel-sel menjadi radiosensitif namun secara perhitungan statistik didapatkan nilai $p$ yang tidak bermakna $(p=1,000)$. Artinya masih terdapat penderita dengan ekspresi VEGF tinggi yang tidak mempunyai respons atau penderita dengan ekspresi VEGF rendah yang respons dengan terapi kemoradiasi. Hal ini menunjukkan bahwa faktor oksigen saja tidak cukup untuk memprediksi radiosensitivitas tumor, juga dapat disebabkan berbeda-bedanyanilai cutoffekspresi TF pada KNF. Hasil penelitian ini sesuai dengan penelitian Krishna dkk. ${ }^{14}$ yang meneliti ekspresi VEGF pada KNF dan menghubungkannya dengan status EBV. Krishna dkk. pada KNF dengan EBV positif mendapatkan hasil VEGF positif pada 28 orang dan VEGF negatif pada 9 orang.

Beberapa penelitian menemukan peran $\mathrm{TF}$ pada kejadian metastasis, angiogenesis, serta perumbuhan tumor. Mekanisme yang diajukan adalah ikatan faktorVIIa dengan TF menyebabkan proteolisis protease activated receptor (PAR)-2 dan fosforilasi domain sitoplasma TF sehingga mengaktivasi jalur sinyal sel yang pada akhirnya akan menyebabkan angiogenesis, survival sel ganas, dan metastasis. ${ }^{8}$ Hubungan TF dengan progresivitas dan angiogenesis sebuah kanker sudah banyak diteliti. Tissuefactoryang berikatan dengan ligan faktor VII/VIIa akan menginisiasi kaskade koagulasi. Protease juga memiliki peran pada angiogenesis lewat aktivasi PAR pada sel tumor yang menyebabkan aktivasi intraseluler. ${ }^{16}$ Aktivasi PAR-2 sinyal TF-VIIa telah diteliti pada beberapa penelitian in vitro dapat menghambat apoptosis, juga menyebabkan migrasi sel dan angiogenesis. ${ }^{9}$ Penelitian tersebut masih terbatas pada karsinoma payudara, hepatoseluler, otak, kolorektal, ovarium, dan pankreas. ${ }^{16}$

Pada penelitian ini subjek dengan ekspresi TF tinggi ( $\geq 33 \%$ ) sebanyak 20 orang dan ekspresi TF rendah $(<33 \%)$ sebanyak 10 orang (Tabel 3). Dari 20 orang dengan ekspresi TF tinggi didapatkan 16 orang respons terhadap terapi kemoradiasi dan 4 orang tidak respons. Keadaan ini sesuai dengan hipotesis penelitian ini yang mendukung teori bahwa TF dapat menginduksi pelepasan kemokin proangiogenik dan faktor pertumbuhan misalnya VEGF sehingga secara tidak langsung TF dapat merefleksikan oksigen di jaringan tumor dan sel menjadi radiosensitif. Secara perhitungan statistik didapatkan $\mathrm{p}=0,657$. Hal ini menunjukkan bahwa masih banyak faktor biologi lain yang berperan dalam menentukan 
radiosensitivitas sel tumor selain faktor oksigen dan diperkirakan fungsi TF sebagai prokoagulan dan fungsi proteolitik tidak diperlukan dalam pengaturan produksi VEGF seperti yang terjadi pada sel tumor gaster ${ }^{17}$ Keadaan ini juga dapat disebabkan belum ada kesepakatan nilai cut-off ekspresi TF untuk KNF.

Hasil penelitian ini berbeda dengan hasil yang didapat Regina dkk. ${ }^{12}$ yang meneliti ekspresi TF pada karsinoma paru. Regina dkk. mendapatkan hasil ekspresi TF tinggi sebanyak 17 orang dan ekspresi rendah pada 47 orang. Pada penelitian tersebut dimasukkan semua stadium karsinoma paru dan menghubungkan ekspresi TF dengan ekspresi VEGF dan progresivitas penyakit.

Bervariasinya hasil penelitian TF disebabkan variasi ekspresi TF seperti yang telah dilaporkan pada beberapa penelitian. Ekspresi TF sangat tinggi pada jaringan yang diambil dari jaringan metastasis dibanding dengan jaringan tumor karena TF terbawa saat metastasis hematogen sel kanker dan secara tidak langsung menyebabkan pertumbuhan tumor. ${ }^{18}$ Di sisi lain, ekspresi TF sangat bervariasi antara satu tumor dan tumor yang lain, salah satunya bergantung pada mutasi onkogen. ${ }^{12}$ Pada KNF belum diketahui mutasi onkogen, sedangkan pada kanker kolorektal ${ }^{10}$ dan karsinoma paru ${ }^{12}$ diketahui k-ras mutasi sehingga ekspresi TF akan semakin meningkat.

Simpulan, tidak terdapat perbedaan ekspresi TF dengan ekspresi VEGF pada penderita KNF stadium lanjut berdasarkan respons terapi kemoradiasi.

\section{Daftar Pustaka}

1. Chan ATC. Nasopharyngeal carcinoma. Ann Oncol. 2010;21(S7):308-12.

2. Farhat. Vascular endothelial growth pada karsinoma nasofaring. MKN. 2009;42(1): 59-65.

3. NCCN Clinical Practice Guidelines in Oncology, Head and Neck Cancers, version 2. 2013

4. Agulnik M, Siu LL. State- of- the-art management of nasopharyngeal carcinoma: current and future directions. $\mathrm{Br} \mathrm{J}$ Cancer. 2005;92:799-806

5. Kamijo T, Yokose T, Hasebe T, Yonou H, Sasaki $\mathrm{S}$, Hayashi, dkk. potential role of microvessel density in predicting radiosensitivity of $\mathrm{T} 1$ and T2 stage laryngeal squamous cell carcinoma treated with radiotherapy. Clin Cancer Res. 2000;6:3159-65

6. Kurnianda J, Hardianti MS, Harijadi, Hariadi
KW, Purwanto I, Haryana SM, dkk. Elevation of vascular endothelial growth factor in Indonesian advanced stage nasopharyngeal carcinoma. Kobe J Med Sci. 2009;55(2):36-44

7. Kerbel RS. Tumor angiogenesis. N Engl J Med. 2008;358:2039-49.

8. Bluff JE, Brown NJ, Reed MWR, Staton CA. Tissue factor, angiogenesis and tumour progression. Breast Cancer Res. 2008;10:204-14

9. Ruf W, Disse J, Carneiro-Lobo TC, Yokota N, Schaffner F. Tissue factor and cell signalling in cancer progression and thrombosis. J Thromb Haemost. 2011;9(Supp1):306-15.

10. Yu JL, May L, Lhotak V, Shahrzad S, Shirasawa S, Weitz JI, dkk. Oncogenic events regulate tissue factor expression in colorectal cancer cells: implications for tumor progression and angiogenesis. Blood. 2005;105(4):1734-41

11. Koizume S, Jin MS, Miyagi E, Hirahara F, Nakamura Y, Sakuma Y, dkk. Activation of cancer cell migration and invasion by ectopic synthesis of coagulation factor VII. Cancer Res. 2006;66:9453-60

12. Regina S, Rollin J, Blechet C, Iochmann S, Reverdiau P, Gruel Y. Tissue factor expression in non-small cell lung cancer: relationship with vascular endothelial growth factor expression, microvascular density, and k-ras mutation. J Thor Oncol. 2008;3(7):689-96

13. Segawa Y, Oda, Yamamoto $H$, Shiratsuchi $\mathrm{H}$, Hirakawa N, Komune S, dkk. Close correlation between CXCR4 and VEGF expression and their prognostic implication in nasopharyngeal carcinoma. Oncol Rep. 2009;21:1197-202

14. Krishna SM, James S, Balaram P. Expression of VEGF as prognosticator in primary nasopharyngeal cancer and its relation to EBV status. Virus Res. 2006;115(1):85-90

15. Lawrence TS, Ten Haken RK, Giaccia A. principles of radiation oncology. Dalam: DeVita VT, Hellman S, Rosenberg SA, penyunting Cancer principles and practice of oncology. Edisi ke-8. Philadelphia: Lippincott Williams \& Wilkin; 2008. hlm. 307-33.

16. McEachron TA and Mackman N. Tissue factor expression by malignant cells contributes tumor progression. JCD 2010 [diunduh 22 Juni 2013]. Tersedia dari: www.slmhematology.com.

17. Zhang J, Ding J, Zhang X, Shao X, Hao Z. Regulation of vascular endothelial growth factor (VEGF) and angiogenesis by tissue factor (TF) in SGC-7901 gastric cancer cells. Cancer Biol Ther. 2005:4;769-72. 
Een: Perbedaan Ekspresi Vascular Endothelial Growth Factor dan Ekspresi Tissue Factor

18. Khorana AA, Ahrendt SA, Ryan CK, Francis CW, Hruban RH, Hu YC, dkk. Tissue factor expression, angiogenesis, and thrombosis in Pancreatic Cancer. Clin Cancer Res. 2007;13:2870-5 